\title{
The Implications of President Al-Bashir's Visit to South Africa for International and Domestic Law
}

Accepted for publication in the 2015/5 Journal of International Criminal Justice

\author{
Erika de Wet ${ }^{*}$
}

\begin{abstract}
This article assesses whether the South African North-Gauteng High Court correctly decided in June 2015 that the government violated international and domestic law when failing to arrest President Al Bashir of Sudan, while attending an AU summit in the country, and surrendering him to the ICC. The international law assessment turns on one's interpretation of the interrelationship between Articles 27(2) and 98(1) of the ICC Statute, as well UNSC Resolution 1593 (2005). The national law assessment turns on the status in the domestic legal order of the Rome Statute of the International Criminal Court Act, 2002, as well as a hoststate agreement which the government entered into with the AU Commission for the purposes of the organization of the AU summit. The starting point for this assessment is section 231 of the Constitution of the Republic of South Africa, 1996 which regulates the status of treaties in the domestic legal order. In addition, section 233 determines that domestic law has to be interpreted in accordance with international law as far as reasonably possible. The role of interpretation is of particular importance when determining the impact of UNSC 1593 (2005) and the Pre-Trial Chamber II decision against South Africa within the domestic legal order.
\end{abstract}

\section{Introduction}

South Africa has been a party to the Rome Statute of the International Criminal Court ('ICC Statute') since 17 July 1998. The South African parliament subsequently incorporated the obligations under the ICC Statute by means of the Implementation of the Rome Statute of the International Criminal Court Act, 2002 ('Implementation Act'). ${ }^{1}$ Through such accession and incorporation South Africa became bound by the obligations under the ICC Statute, both

* $\quad$ B.Iur, LL.B, LL.D (University of the Free State, South Africa); LL.M (Harvard); Habil (Zurich); designated SARCHI Professor of International Constitutional Law, Faculty of Law, University of Pretoria, South Africa; Honorary Professor, Faculty of Law, University of Bonn, Germany. [erika.dewet@up.ac.za]

1 The Implementation of the Rome Statute of the ICC Act 27 of 2002, available online at http://www.gov.za/sites/www.gov.za/files/a27-02.pdf (visited 30 July 2015). See extensively M. du Plessis, 'South Africa's Implementation of the ICC Statute. An African Example', 5 Journal of International Criminal Justice (JICJ) (2007) 460. 
internationally and on the domestic level. ${ }^{2}$ At the heart of the international obligations contained in the ICC Statute is the duty of state parties to cooperate with the International Criminal Court ('ICC') contained in Article 86. ${ }^{3}$ In line with this general obligation, Article 89(1) obliges state parties to comply with requests for arrest and surrender. ${ }^{4}$ This obligation has also been implemented in South African domestic law by means of section 10 of the Implementation Act.

The scope of this obligation to comply with a request for arrest or surrender became of central importance to South Africa during the visit of Sudanese President Al Bashir for the purpose of attending a summit of the African Union ('AU') which was hosted in Johannesburg between 14 and 17 June 2015. ${ }^{5}$ Previously, on 4 March 2009 and 12 June 2010, the ICC had issued two arrest warrants against President Al Bashir for respectively seven counts of war crimes and crimes against humanity and three counts of genocide. ${ }^{6}$ In the wake of the 2009 and 2012 ICC arrest warrants and relying on Article 59 of the ICC Statute, the ICC requested state parties to the Statute, including South Africa, to arrest Al Bashir in the event that he came into their jurisdictions. ${ }^{7}$ In doing so, the ICC relied on United Nations Security Council ('UNSC') Resolution 1593 (2005), ${ }^{8}$ in which the UNSC referred the situation in Darfur (Sudan) to the ICC in accordance with its Chapter VII powers.

2 See Southern African Litigation Centre $v$ the Minister of Justice and Constitutional Development and Others, High Court of South Africa, Gauteng Division, Pretoria, Case Number: 27740/2015, 24 June 2015 § 11, available online at http://www.southernafricalitigationcentre.org/cases/ongoing-cases/south-africasudanseeking-implementation-of-icc-arrest-warrant-for-president-bashir/ (visited 30 July 2015).

3 Art. 86 ICCSt. determines that: 'States Parties shall, in accordance with the provisions of this Statute, cooperate fully with the Court in its investigation and prosecution of crimes within the jurisdiction of the Court.'

4 Sec. 89(1) stipulates that: 'The Court may transmit a request for the arrest and surrender of a person, together with the material supporting the request outlined in art 91, to any State on the territory of which that person may be found and shall request the cooperation of that State in the arrest and surrender of such a person. States Parties shall, in accordance with the provisions of this Part and the procedure under their national law, comply with requests for arrest and surrender.' See also D. Akande, 'The Legal Nature of Security Council Referrals to the ICC and its Impact on Al Bahir’s Immunities’, 7 JICJ (2009) 334.

5 For the background see Decision following the Prosecutor's Request for an Order further clarifying that the Republic of South Africa is under the Obligation to immediately Arrest and Surrender Omar Al Bashir, The Prosecutor v. Omar Hassan Ahmad Al Bashir (ICC-02/0501/09), Pre-Trial Chamber II, 13 June 2015 ['Al Bashir (South Africa) decision'].

$6 \quad$ Al Bashir (South Africa) decision, supra note 5, § 2.

7 As pointed out also by the North-Gauteng High Court decision, supra note 2, § 12.

8 In SC Res. 1593, 31 March 2005, the UNSC determined that: ‘... Acting under Chapter VII of the Charter of the United Nations,

1. Decides to refer the situation in Darfur since 1 July 2002 to the Prosecutor of the International Criminal Court;

2. Decides that the Government of Sudan and all other parties to the conflict in Darfur, shall cooperate fully with and provide any necessary assistance to the Court and the Prosecutor pursuant to this resolution and, while recognizing that States not party to the Rome Statute have no obligation under the Statute, urges all States and concerned regional and other international organizations to cooperate fully;... 
On 13 June 2015, the day of Al Bashir's arrival in South Africa, the ICC Pre-Trial Chamber II made an order that South Africa immediately arrest and surrender Al Bashir. ${ }^{9}$ On the same day the Southern African Litigation Centre (a prominent non-governmental organization in the field of human rights) brought an urgent application to the Gauteng Division (Pretoria) of the High Court of South Africa ('the North-Gauteng High Court'), seeking and order that the South African authorities arrest and surrender Al-Bashir. The Court subsequently granted an order that the South African authorities are 'compelled to take all reasonable steps to arrest President Bashir'. ${ }^{10}$ On 15 June 2015 the North-Gauteng High Court ordered the government to take all reasonable steps to prepare to arrest President Bashir and detain him, pending a formal request for his surrender from the ICC. ${ }^{11}$ In addition, the North-Gauteng High Court ordered the government to take all necessary steps to prevent his departure. It further insisted that the government effect service of the order on the officials in charge of every point of entry into and exit from the Republic. The government was directed to provide proof of service, identifying the name of each person on whom the order was served. ${ }^{12}$ It subsequently transpired that in spite these court orders, Al Bashir had left the country by 16 June $2015 .^{13}$

During the hearing before the North-Gauteng High Court the South African government submitted that $\mathrm{Al}$ Bashir enjoyed immunity from arrest in South Africa. ${ }^{14}$ It argued that after agreeing in January 2015 to host the AU summit, the government entered into a host-state agreement with the AU Commission, for the purposes of the organization of the summit. This agreement was concluded around 4 June $2015 .{ }^{15}$ In accordance with Article VIII of the hoststate agreement, privileges and immunities were provided for the duration of the meeting to the members of the AU Commission and staff members, as well as the delegates and other representatives of inter-governmental organisations attending the meetings. As far as the

The UNSC Resolution was adopted with 11 in favour (including Tanzania and Benin) to none (while Algeria along with Brazil, China and the United States abstained). Se L. Condorelli and A. Ciampi, 'Comments on the Security Council Referral of the Situation in Darfur to the ICC', 3 JICJ (2005) 590, at 591-592; Akande, supra note 4, 335.

9 Al Bashir (South Africa) decision, supra note 5, § 2

10 D. Tladi, 'The Duty on South Africa to Arrest and Surrender Al-Bashir under South African and International Law: Attempting to Make a Collage from an Incoherent Framework' (2015) 1, available online at http://ssrn.com/abstract=2626490 (visited 30 July 2015).

11 North-Gauteng High Court decision, supra note 2, § 2.

12 Ibid., § 6.

13 Ibid., § 3.

14 Answering Affidavit of Respondent (North-Gauteng High Court decision, supra note 2), § 3, available online at http://www.southernafricalitigationcentre.org/cases/ongoing-cases/south-africasudan-seekingimplementation-of-icc-arrest-warrant-for-president-bashir/ (visited at 30 July 2015).

15 See the North-Gauteng High Court decision, supra note 2, § 13-14. The government further submitted that all invitations extended were the sole responsibility of the AU. 
nature and scope of the privileges and immunities applicable were concerned, the host-state agreement referred to those contained in section C and D, Articles V and VI of the General Convention on the Privileges and Immunities of the Organisation of African Unity ('OAU Convention’). These inter alia included immunity from arrest and detention. ${ }^{16}$

The host state agreement (including the privileges and immunities contained therein by reference to the OAU Convention) was implemented in South African law a day later on 5 June 2015 through a ministerial notice in the Government Gazette. ${ }^{17}$ This was done in accordance with sections 5(3) and 7(2) of the Diplomatic Immunities and Privileges Act 37 of 2001 ('DIPA'), which inter alia serves to implement the Vienna Convention on Diplomatic Relations $1961 .^{18}$ It is noteworthy that section 4 of the DIPA further confirms that heads of state are immune from civil and criminal jurisdiction to the extent afforded to them under customary international law. ${ }^{19}$ The customary law immunity of heads of state includes immunity from arrest and is absolute in nature, i.e. applying also in situations where the head of state is accused of having committed an international crime. ${ }^{20}$ The purpose of the immunity is to facilitate the smooth exercise of sovereign functions abroad and to avoid states unduly manipulating their civil and criminal jurisdiction as a mechanism for undermining the exercise of the official functions by foreign state officials. ${ }^{21}$

The North-Gauteng High Court dismissed the claim that Al Bashir enjoyed immunity in the Republic. It based this argument on Article 27(2) of the ICC Statute, which provided that heads of state do not enjoy immunity under its terms. It noted that similar provisions are expressly included in the Implementation Act. As a result, immunity that might otherwise

16 Ibid., $\S \S$ 15-16. The text of the OAU Convention is available online at http://www.au.int/en/sites/default/files/GENERAL_CONVENTION_PRIVILEGES_IMMUNITIES_ORGA NIZATION_AFRICAN\%20UNITY_0.pdf (visited 30 July 2015).

17 Government Gazette No. 38860, available online at http://www.gov.za/sites/www.gov.za/files/38860_gon470.pdf (visited 30 July 2015); North-Gauteng High Court decision, supra note 2, § 17.

18 North-Gauteng High Court decision, ibid. The chapeau of sec. 5 of the DIPA refers to 'Immunities and privileges of United Nations, specialised agencies and other international organisations'. Sec. 5(3) in turn determines that: 'Any organisation recognised by the Minister for the purposes of this section and any official of such organisation enjoy such privileges and immunities as may be provided for in any agreement entered into with such organisation or as may be conferred on them by virtue of sec 7 (2).' This latter section determines that: 'The Minister may in any particular case if it is not expedient to enter into an agreement [conferring privileges and immunities] as contemplated in sub-sec (1) and if the conferment of immunities and privileges is in the interest of the Republic, confer such immunities and privileges on a person or organisation as may be specified by notice in the Gazette'. The text of the DIPA is available online at http://www.gov.za/documents/diplomatic-immunities-and-privileges-act (visited on 30 July 2015).

19 See also North-Gauteng High Court decision, supra note 2, § 28.2

20 Judgement, Certain Questions of Mutual Assistance in Criminal Matters (Djibouti v France), ICJ Reports 2008, 4 June 2008, § 170; Judgment on Arrest Warrant of 11 April 2000, Democratic Republic of the Congo $v$ Belgium Judgment, ICJ Reports, 14 February 2002, § 54; Akande, supra note 4, 334; P. Gaeta, 'Does President Al Bashir Enjoy Immunity from Arrest?', 7 JICJ (2009) 315, at 318.

21 Gaeta, supra note 20, at 320. 
have attached to President Bashir as head of state is excluded or waived in respect of crimes and obligations under the Rome Statute. $^{22}$ The North-Gauteng High Court further underscored that the ICC Pre-Trial Chamber II had expressly confirmed that the immunities granted to President Bashir under international law and attaching to his position as head of state have been implicitly waived by the UNSC, and that South Africa is consequently under an obligation to arrest and surrender him. ${ }^{23}$ In addition, it regarded the immunities introduced via the host-state agreement as having secondary (subordinate) status to the Implementation Act in South African domestic law. ${ }^{24}$ The North-Gauteng High Court further opined that the AU decision of 12 October 2013 according to which no serving head of state shall be required to appear before any international court or tribunal during their term of office had mere persuasive status in the domestic legal order. ${ }^{25}$

The subsequent analysis will assess whether the North-Gauteng High Court came to the right conclusion, both in terms of the applicable international and domestic law. As will be illustrated below, the international law assessment turns on one's interpretation of the interrelationship between Articles 27(2) and 98(1) of the ICC Statute, as well UNSC Resolution 1593 (2005). This analysis will inter alia make reference to the ICC Pre-Trial Chamber II decision of 14 April 2014 against the Democratic Republic of Congo ('DRC'). The circumstances of that decision were very similar to the one against South Africa. It resulted from a visit by Al Bashir to the DRC in 2014, in order to attend a meeting of the Common Market for Eastern and Southern Africa ('COMESA'). ${ }^{26}$ The DRC, a state party to the ICC Statute, failed to comply with a request for arrest and surrender of Al Bashir to the ICC. ${ }^{27}$ It justified its position by relying on the AU decision not to surrender any sitting head of state to the ICC. ${ }^{28}$ The national law assessment turns on the status of the Implementation Act and the host-state agreement in the domestic legal order, as well as the requirement in section 233 of the Constitution of the Republic of South Africa, 1996 ('Constitution') that domestic law has to be interpreted in an accordance with international law as far as reasonably possible. The role of interpretation is of particular importance when determining

22 North-Gauteng High Court decision, supra note 2, § 28.8.

23 Ibid., § 28.9.

24 Ibid., § 31.

25 Ibid., § 28.13.3.

26 Decision on the Cooperation of the Democratic Republic of the Congo regarding Omar Al-Bashir's Arrest and Surrender to the Court, The Prosecutor v Omar Hassan Ahmad Al Bashir (ICC-02/05-01/09-195), PreTrial Chamber II, 9 April 2014, § 29. ['Al Bashir (DRC) decision’].

27 See extensively N. Boschiero, 'The ICC Judicial Finding on Non-cooperation Against the DRC and No Immunity for Al-Bashir Based on UNSC Resolution 1593’, 13 JICJ (2015) 625.

28 North-Gauteng High Court decision, supra note 2, § 31; Al Bashir (DRC) decision, supra note 26 , § 19. 
the impact of UNSC 1593 (2005) and the Pre-Trial Chamber II decision against South Africa within the domestic legal order.

\section{2. (Lack of) of Immunity of Al Bashir under International Law}

Whether Al Bashir enjoyed immunity that would prevent a state party to the ICC Statute (in this case South Africa) from arresting and surrendering him to the ICC depends on whether immunities provided by customary international and/ or treaty law have either been removed by the ICC Statute and/ or UNSC Resolution 1593 (2005). As far as the ICC Statute is concerned Article 27(2) and its relationship with Article 98 is of prime importance in answering the immunity question.

\section{A. The Relationship between Articles 27(2) and 98 ICC Statute}

Article 27(2) establishes that 'Immunities or special procedural rules which may attach to the official capacity of a person, whether under national or international law, shall not bar the Court from exercising its jurisdiction over such a person. ${ }^{29}$ Article 98(1) for its part confirms the customary international immunities pertaining to high officials of non-state parties, ${ }^{30}$ while Article 98(2) reaffirms that the ICC may not request a state party to surrender someone to the ICC in violation of immunities provided in an international agreement with a third state. ${ }^{31}$ In both instances foreseen by Article 98, the ICC can only proceed with a request for arrest and surrender if the cooperation of the third state has been obtained. There are several issues to consider when assessing the relationship between Articles 27(2) and 98. The first concerns the different fora before which immunity can be at issue (international and national courts); the second are the implications of Article 27(2) for the immunities of state parties to the ICC Statute on the one hand and non-state parties on the other. This latter issue is in turn affected by the implications of UNSC Resolution 1593 (2005).

The relevance of the immunity issue before both the ICC and national courts becomes clear if one keeps in mind that in order to obtain custody over a suspect, the ICC is dependent on the cooperation of states, one of which will have to arrest a suspect such as $\mathrm{Al}$

29 Art. 27(1) ICCSt.

30 Ibid., Art. 98(1) determines: 'The Court may not proceed with a request for surrender or assistance which would require the requested State to act inconsistently with its obligations under international law with respect to the State or diplomatic immunity of a person or property of a third State, unless the Court can first obtain the cooperation of that third State for the waiver of the immunity'.

31 Ibid., Art. 98(2, determines: 'The Court may not proceed with a request for surrender which would require the requested State to act inconsistently with its obligations under international agreements pursuant to which the consent of a sending State is required to surrender a person of that State to the Court, unless the Court can first obtain the cooperation of the sending State for the giving of consent for the surrender.' 
Bashir and turn him over to the ICC. ${ }^{32}$ So, on the one hand there is the question whether head of state immunity would apply before the ICC itself, inter alia preventing it from issuing and circulating an international arrest warrant. On the other hand the question arises whether such immunity would bar foreign national authorities from arresting and surrendering him. ${ }^{33}$ Article 27(2) will indeed remove any immunities before the ICC as well as foreign national courts where both states involved (the state whom the head of state represents, as well as the arresting and surrendering state) are parties to the ICC Statute. This is reflected by the explicit references to national and international law immunities in Article 27(2). ${ }^{34}$ Since the ICC itself is concerned only with international immunities applicable to international courts, ${ }^{35}$ the reference to national immunities would necessarily refer to those immunities applicable to national authorities. ${ }^{36}$

Any other interpretation in a situation where both affected states are parties to the ICC Statute would render Article 27(2) meaningless and make it impossible for the ICC to obtain custody over indicted high-level perpetrators of international crimes. Given the absence of its own powers to arrest, it is entirely reliant on national authorities for arresting suspects and surrendering them into the custody of the ICC. ${ }^{37}$ Therefore, if Article 27(2) would not simultaneously lift immunity before the ICC and foreign domestic authorities, the ICC would only be able to exercise jurisdiction in the highly unlikely instances where an indicted head of state surrendered voluntarily, or was surrendered by the home state ${ }^{38}$ (in that case, immunity under customary international law would not apply at all, being applicable only before foreign authorities. ${ }^{39}$ ) The ICC's jurisdiction would for all practical purposes become

32 See also Boschiero, supra note 27, at 626.

33 Akande, supra note 4, at 336.

34 Ibid., 336, 339. See also Gaeta, supra note 20, 325 according to whom the ICCSt. derogated from the customary international law rules extending immunities to heads of state before national authorities in as far as it concerns the contracting states.

35 Once could ask whether it was indeed necessary for the ICC to remove international immunities of officials appearing before itself. See Decision on Immunity from Jurisdiction, The Prosecutor v Charles Ghankay Taylor (SCSL-2003-01-I), Appeals Chamber, 31 May 2004. In this decision of the Special Tribunal for Sierra Leone, it determined that the rules of international law extending personal immunities to heads of state were only applicable on the national level and did not apply before international tribunals. See also Arrest Warrant case, supra note 20, § 62; However, whatever uncertainty may have remained in this regard was removed in relation to the ICC through Art. 27(2) See also Gaeta, supra note 20, 317, 321-322, who notes that the jurisdiction of international criminal courts, functioning on behalf of the international community, cannot be conceived as an expression of the sovereign authority of any particular state upon that of another state.

36 Akande, supra note 4, at 338

37 Ibid., 338.

38 Ibid., 338.

39 Boschiero, supra note 27, at 646. 
inoperable, which would be contrary the principle of treaty interpretation that requires every treaty provision to have meaning. ${ }^{40}$

However, as is well known, only South Africa is a party to the ICC Statute, while Sudan is not. In such an instance the immunities referred to in Article 98 can bar arrest at the national level, in the absence of a waiver of the customary immunity by Sudan or of the treaty (host state) immunities by the AU. ${ }^{41}$ While such an interpretation does limit the operational scope of Article 27(2), it takes proper account of elementary principles of treaty law. ${ }^{42}$ Nothing in the ICC Statute can remove the immunity belonging to non-state parties as that would create obligations for third states in violation of the pacta tertiis rule and also render Article 98 meaningless. ${ }^{43}$

This position was endorsed also by the ICC Pre-Trial Chamber II in its decisions against the DRC and South Africa. It acknowledged that the question of personal immunity of the head of state can arise at the national level, as Article 27(2) of the ICC Statute had to be confined to state parties. ${ }^{44}$ In taking this stance, the ICC Pre-Trial Chamber distanced itself implicitly from the much criticized reasoning of the ICC Pre-Trial Chamber 1 in its 2011 decisions against Malawi and Chad, which also concerned the failure to comply with the ICC's request for arrest and surrender of Al Bashir. ${ }^{45}$ In those decisions, ICC Pre-Trial Chamber I claimed the existence of a special customary international law exception to immunities of heads of state, despite the absence of state practice supporting its position and in the process ignoring the existence of Article 98(1) of the ICC Statute. ${ }^{46}$

The much improved reasoning by the Pre-Trial Chamber II decisions against the DRC and South Africa was most likely in response to the strong criticisms in literature for inter alia refusing to address the tension between Articles 27(2) and 98 of the ICC Statute. ${ }^{47}$ Some commentators blamed Pre-Trial Chamber II for not having addressed explicitly the Malawi

40 Appellate Body Report, United States - Standards for Reformulated and Conventional Gasoline, WTO Doc. WT/DS2/AB/R, 29 April 1996, at 23; Akande, supra note 4, 336.

41 Gaeta, supra note 20, at 328.

42 Akande, supra note 4, at 338.

43 See Condorelli \& Ciampi, supra note 8, at 593; Akande, supra note 4, at 339; Tladi, supra note 9, at 9.

44 Al Bashir (DRC) decision, supra note 26, § 26; Boschiero, supra note 27, at 630.

45 In two decisions of 12 and 13 December 2011 Pre-Trial Chamber I rebuked Malawi and Chad for failing to comply with the cooperation requests issued by the ICC to arrest and surrender Omar Al-Bashir during his visits to their territories (ICC-02/05-01/09-139; and ICC-02/05-01/09-1). Pre-Trial Chamber II also issued a second decision on non-compliance in relation to Chad on 26 March 2013 (ICC-02/05-01/09). See Boschiero, supra note 27, at 630; D. Tladi, 'The ICC Decisions on Chad and Malawi. On Cooperation, Immunities, and Article 98', 11 JICJ (2013) 199, 199 ff.

46 Boschiero, supra note 27, 637; Tladi, supra note 9, at 2.

47 Boschiero, ibid., at 638-639. 
and Chad decisions of Pre-Trial Chamber $1 .^{48}$ However, this criticism ignores the fact that it is rare for chambers of international criminal courts and tribunals to criticize openly a decision of a different chamber (or even for the Appeals Chamber to criticize Trial or PreTrial Chambers or even more so to criticize one of its previous decisions). While this may be unsatisfactory from an intellectual point of view, it is a reality of international adjudication. Moreover, this omission on the part of Pre-Trial Chamber II does not change the fact that its reasoning as such was fundamentally correct. ${ }^{49}$

In essence therefore, it has been established that the immunity belonging to non-state parties to the ICC Statute such as Sudan is recognized in Article 98 ICC Statute and that Article 27(2) has to be interpreted accordingly. But this is not the end of the matter, since the UNSC has adopted resolution 1593 (2005) under Chapter VII of the UNSC, according to which 'the Government of Sudan, and all other parties to the conflict in Darfur, shall cooperate fully with and provide any necessary assistance to the Court and the Prosecutor pursuant to this resolution'. ${ }^{50}$ The implications of this resolution for Sudan on the one hand, as well as ICC member states on the other, are decisive for determining whether President Bashir still enjoyed immunity under international law, as well as whether an ICC member state such as South Africa is required to give effect to an ICC request for arrest and surrender. 51

\section{B. The Impact of UNSC Resolution 1593 (2005) on Articles 27(2) and 98 ICC Statute}

In order to assess the implications of UNSC Resolution 1593 (2005), one needs to distinguish three issues. First, there is the question whether this resolution triggered the ICC's jurisdiction. Second, the meaning of the obligation to 'cooperate fully' has to be assessed. Does it imply that Sudan has to waive the immunity of Al Bashir? Third, the implications of such a waiver of immunity (if it had occurred) for states other than Sudan have to be examined, in particular for state parties to the ICC Statute such as South Africa.

As far as the jurisdictional issue is concerned, the referral to the ICC in UNSC Resolution 1593 (2005) triggers the jurisdiction of the ICC, entitling it to undertake investigations and prosecutions in relation to Sudan, i.e. the situation in Darfur. The ICC Statute clearly

48 See P. Gaeta, 'The ICC Changes its Mind on Immunity from Arrest of President Al Bashir, but it is Wrong Again’ Opinio Juris, 23 April 2014, available at http://opiniojuris.org/2014/04/23/guest-post-icc-changesmind-immunity-arrest-president-al-bashir-wrong/ (last visited 3 September 2015).

49 See also Boschiero, supra note 27, at 638-639.

50 SC Res. 1593, supra note 8, § 2.

51 Akande, supra note 4, at 340. 
provides for such referrals in Article 13(b) of its Statute. ${ }^{52}$ The purpose of this article was to enable the ICC to undertake investigations and prosecutions in states not party to the ICC Statute. ${ }^{53}$ Since the ICC itself is - unlike all its member states - not a party to the United Nations ('UN') Charter, it would not be able to receive any Chapter VII referral unless it consented to such a decision. ${ }^{54}$ This indeed was done by Article 13(b) and even though UNSC Resolution 1583 (2003) does not explicitly refer to Article 13(b) of the ICC Statute, the referral necessarily took place under that article.

Some authors have criticized the fact that the paragraph 2 of Resolution1593 (2005) does not explicitly state that Sudan's full cooperation with the ICC has to take place in accordance with the ICC Statute. ${ }^{55}$ However, one has to keep in mind that the ICC statutory framework is the only one within which the ICC can operate. ${ }^{56}$ Article 1 of the ICC Statute determines that the 'jurisdiction and functioning of the Court shall be governed by the provisions of the Statute.' There was therefore no need in UNSC Resolution 15(3) to determine explicitly that this has to be the case. ${ }^{57}$ In this context one should also be careful not to over-extend the analogy with UNSC resolution 827 (1993) that created the ad hoc Criminal Tribunal for the former Yugoslavia (ICTY), which explicitly determined that state cooperation had to take place in accordance with the ICTY Statute. ${ }^{58}$ The ICTY was a creature and sub-organ of the UNSC and the same resolution that created the ICTY also created its statute. Since that type of structure was a complete novelty in 1993, it was necessary for the UNSC to spell out the relationship between the ICTY, its Statute and states. The ICC on the other hand was created by a treaty and had already been in operation several years before it received its first UNSC

52 Art. 13(b) ICCSt., determines that the ICC may exercise jurisdiction if 'A situation in which one or more of [the crimes in Art. 5] appears to have been committed is referred to the Prosecutor by the Security Council acting under Chapter VII of the Charter of the United Nations;...'

53 Akande, supra note 4, at 340; idem., 'The Effect of Security Council Resolutions and Domestic Proceedings on State Obligations to Cooperate with the ICC', 10 JICJ (2012) 299, at 304. This is because the main purpose of allowing UNSC referrals is to extend the jurisdiction of the ICC to situations in which it would otherwise not have jurisdiction, due to the fact that those situations occur in non-states parties.

54 Akande (Effects of Security Council Resolutions), supra note 53, at 308.

55 G. Sluiter, 'Obtaining Cooperation from Sudan - Where is the Law?', 6 JICJ (2008) 871, at 876-877.

56 Akande, supra note 4, at 340; Gaeta, supra note 20, 324, Sluiter, supra note 55, at 381.

57 Akande, ibid., at 340-341. It is also important to note that any attempt of the UNSC to impose a different framework on the ICC would be illegal, as it does not have competence to suspend ore amend the ICCSt., the latter not being a party to the UN Charter. The UNSC therefore wisely refrained from providing any procedures in the referral that would add or amend the provisions of the ICCSt..

58 As noted by Sluiter, supra note 55, at 877; SC Res. 817, May 25 1991, § 4 determined that: 'Decides that all States shall cooperate fully with the International Tribunal and its organs in accordance with the present resolution and the Statute of the International Tribunal and that consequently all States shall take any measures necessary under their domestic law to implement the provisions of the present resolution and the Statute, including the obligation of States to comply with requests for assistance or orders issued by a Trial Chamber under Article 29 of the Statute'. 
referral. To expect the UNSC to articulate state cooperation in referrals to the ICC, as it did in its founding resolution of the ICTY, would ignore these important differences in context.

The next question to be addressed is how the duty on Sudan to cooperate fully impacts the immunity of Al Bashir, since having established that the ICC has jurisdiction over the Darfur situation, does not in itself determine whether any immunity has been lifted, nor to what extent other states would be affected in case immunity was lifted. ${ }^{59}$ At most, one could claim that the referral requires state parties such as South Africa to cooperate with the ICC in accordance with the ICC Statute. This follows from Article 86 of the ICC Statute, according to which states parties shall, in accordance with the provisions of this Statute, cooperate fully with the ICC in its investigation and prosecution of crimes within the ICC's jurisdiction. On the one hand, the full cooperation required by this article necessarily requires member states to cooperate in all investigations and prosecutions, including those resulting from UNSC referrals. ${ }^{60}$ On the other hand, such cooperation does need to be in accordance with the ICC Statute as a whole, which implies that the cooperation must also take account of the potential immunity bars in Article $98 .{ }^{61}$ The obligation to cooperate as such does therefore not in and of itself dispose of the immunity obstacles.

To determine whether Al Bashir's immunity has been lifted, one has to look at the language of the operative part of UNSC Resolution 1593(2005). Before doing so, it is worth recalling that Sudan, as a member of the UN, has to accept binding UNSC measures pertaining to its territory, including any obligations to waive immunity - to the extent the UNSC has indeed imposed them. ${ }^{62}$ This follows from Article 25 of the UN Charter, which obliges member states to accept and carry out UNSC decisions, which notably also includes binding UNSC decisions under Chapter VII of the UN Charter. ${ }^{63}$ In addition, Article 103 of the UN Charter determines that in the event of a conflict between the obligations of the members of the United Nations under the present Charter and their obligations under any other international agreement, their obligations under the present Charter shall prevail' ${ }^{64}$

59 See Gaeta, supra note 20, at 324 who correctly states that the triggering of the jurisdiction of the ICC through a referral does not turn a non-state party into a state party.

60 See also Tladi, supra note 9, at 8 who seems to acknowledge that the UNSC referral triggers the cooperation of ICC member States under the ICCSt..

61 Akande, supra note 4, at 341. See also Akande (Effects of Security Council Resolutions), supra note 53, 304; Gaeta, supra note 20, at 328.

62 Akande (Effects of Security Council Resolutions), supra note 53, at 306.

63 The text of the UN Charter is available online at http://www.un.org/en/documents/charter/chapter5.shtml (visited 30 July 2015). Art. 25 determines that: 'The Members of the United Nations agree to accept and carry out the decisions of the Security Council in accordance with the present Charter'. See also Akande, supra note 4, at 341; Condorelli and Ciampi, supra note 8, at 593.

64 See Akande, ibid., at 335; Boschiero, supra note 27, at 631. 
Sudan would thus have to accept a UNSC obligation to lift immunity, despite any other treaty obligation to the contrary. Moreover, it would also have to lift customary immunities, to the extent that a Chapter VII UNSC Resolution required it to do so. Even though the wording of Article 103 only refers to treaty obligations, states have over time accepted in practice that the UNSC can also oblige states to deviate from customary international law. ${ }^{65}$

In fact, those who claim that the wording of UNSC Resolution 1593(2003) does not lift the immunity of $\mathrm{Al}$ Bashir, do not disagree with the above. ${ }^{66}$ Instead they claim that the wording of paragraph 2 of this resolution is too vague and does not explicitly require a waiver of immunity. ${ }^{67}$ Stated differently, they suggest that the UNSC Council can only waive international law obligations if it does so explicitly. ${ }^{68}$ In the absence of such explicit language, the referral provided for in UNSC Resolution 1593 (2005) merely triggers the jurisdiction of the ICC, nothing more. ${ }^{69}$ As a result, Al Bashir would still enjoy personal immunity under international law vis-à-vis all states and such immunity could only be waived with the consent of the Sudanese government. ${ }^{70}$ This reasoning would mean that South Africa is under an obligation towards Sudan not to arrest and surrender Al Bashir, as it would amount to a violation of his immunity. ${ }^{71}$

The above position, though eloquently argued, is not convincing. First, the submission that the UNSC has to stipulate all deviations from international law explicitly in the resolution itself is not in accordance with well-established and accepted UNSC practice which, in fact, supports exactly the opposite conclusion. Instead of explaining the extent to which states may deviate from international law under a UNSC resolution, Chapter VII resolutions instead indicate what states may not do when deviating from international law in

65 A concrete example includes the UNSC resolutions addressing piracy before the coast of Somalia and which were adopted under Chapter VII of the Charter. These resolutions inter alia permit States to pursue suspected pirates in the territorial waters of Somalia. This is a clear deviation from both treaty and customary norms pertaining to the law of the sea. See e.g. SC Res. 1846, 2 December 2008, $\S 10$ which has most recently been extended by SC Res. 2184, 12 November 2014, § 13. See also A. Paulus \& J. Leiss, 'Article 103', in B. Simma, D.E Khan, G. Nolte, and A. Paulus (eds), The Charter of the United Nations. A Commentary, Vol I (Oxford University Press, 3rd edn., 2012) 2110-2137, at 2133. Contra A. Tzanakopoulos, Disobeying the Security Council: Countermeasures against Wrongful Sanctions (Oxford University Press, 2011), who argues that the UNSC cannot permit States to deviate from customary international law.

66 See Gaeta, supra note 20, at 330 and also Tladi, supra note 9, at 18.

67 Sluiter, supra note 55, at 877-878 claims that the reference to full cooperation is too vague to clarify whether it encompasses the waiving of domestic as well as international obligations that would prevent ICC investigations and prosecutions.

68 Tladi, supra note 9, 18; Gaeta, supra note 20, 330.

69 Geata, ibid.,at 330; see also Sluiter, supra note 55, 876, who notes that the records of the UNSC meeting preceding the adoption SC Res. 1593 does not expand on what is meant by full cooperation.

70 Gaeta, ibid., at 329.

71 Tladi, supra note 9 , at 12. 
accordance with the resolution. All deviations that are not allowed are therefore indicated in the resolution. For example, when imposing binding economic sanctions, or measures pertaining to piracy or terrorism, the respective resolutions will sometimes confirm that states have to act in accordance with international human rights or other relevant international standards. $^{72}$ The UNSC even follows this practice in relation to the most drastic of measures, namely authorizing the use of military force under Chapter VII of the Charter. The wellestablished term of art for authorizing member states to use military force is authorizing 'all necessary means' or 'all necessary measures'. It is generally accepted by states that this would include all military measures, whether aerial or on the ground, unless the UNSC resolution excludes some measures. ${ }^{73}$

In line with this established practice, there is no requirement under international law requiring that the UNSC has to spell out an obligation to lift immunities. The reference to 'full cooperation' in UNSC resolution 1593 (2005) should be taken to mean all required measures under domestic and international law, including the lifting of immunities. ${ }^{74}$ This conclusion is also supported by the textual link between paragraph UNSC Resolution 1593 (2005) and Article 98 of the ICC Statute, both of which referred to 'cooperation'. As indicated above, the cooperation in this article concerns that of a third state for the purpose of waiver of immunity. By referring to 'full cooperation' in paragraph 2, UNSC Resolution 1593 (2005) connects to all articles in the ICC Statute that concern cooperation - including Article 98. The waiving of immunity is thus one step to be taken by Sudan to ensure full cooperation in line with the resolution. This line of argument was confirmed by the ICC PreTrial Chamber II in its decision against the DRC. ${ }^{75}$

Finally, it is arguable that any detailed articulation of the lifting of immunities in the resolution seems out of place if one considers that UNSC Resolution 1593 (2005) was not, as such, concerned with Al Bashir. Its purpose was to refer the situation as a whole to the ICC Prosecutor who - only four years later - issued an arrest warrant for Al Bashir. UNSC referrals are not concerned with single cases or the fate of single individuals, but rather to facilitate investigations and prosecutions as a whole in non-member states. It is therefore to be expected that it contains a general obligation pertaining to cooperation that requires a state

72 See e.g the anti-piracy resolutions such SC Res. 1846, 2 December 2008, § 10 and the preamble to SC Res. 2170, 15 August 2014 concerning the combatting of terrorism.

73 E.g. when authorizing the use of all necessary measures against the Libyan government in SC Res. 1973, 11 March 2011, § 4 the UNSC explicitly excluded ground troops ('foreign occupation force').

74 Al Bashir (DRC) decision, supra note 26, § 29.

75 Ibid., § 29. See also Al Bashir (South Africa) decision, supra note 5, § 9. 
such as Sudan to do all that is necessary to facilitate such investigations (whether by lifting immunity or removing any other legal obstacle). ${ }^{76}$

Having established that UNSC Resolution 1593 (2005) obliged Sudan to lift any immunities extended to him by national or international law, the question arises what this implies for other states. To what extent does a resolution that is addressed at Sudan and the (internal) parties to the conflict generate implicit rights or obligations for other states? Can they rely on the immunities as being lifted and do they have to cooperate with the ICC in arresting and surrendering Al Bashir? Or would they be allowed or even obliged to still recognize Al Bashir's immunity with the argument that UNSC Resolution 1593 (2005) only concerns Sudan? ${ }^{77}$ The starting point for answering these questions is the 1970 Namibia advisory opinion of the International Court of Justice (ICJ). ${ }^{78}$ The decision concerned the UNSC resolution that declared the South African presence in Namibia illegal, ${ }^{79}$ without however imposing any explicit obligations on other states. The ICJ gave a purposive interpretation to the resolution and determined that the UNSC resolution required all states to recognize the illegality of South Africa's presence and to refrain from any acts that would imply the recognition of the legality of South Africa's presence. ${ }^{80}$ All states thus had to accept the legal situation resulting from the UNSC binding decision and act in accordance with such acceptance, as anything less would undermine the efficacy of the principal organ entrusted with the primary responsibility for international peace and security. ${ }^{81}$

If this reasoning is applied to the $\mathrm{Al}$ Bashir scenario, it implies that the Chapter VII character of the obligation on Sudan to lift Al Bashir's immunity requires all UN member states to regard his immunity as having been waived. ${ }^{82}$ For those UN member states that are also state parties to the ICC Statute, it would further imply that the immunity obstacle posed by Article 98 of the ICC Statute, preventing them from cooperating with the ICC on matters pertaining to his arrest and surrender has been removed. ${ }^{83}$ South Africa would not be able to

76 Boschiero, supra note 27, at 648-649.

77 As claimed by Gaeta, supra note 20, at 330.

78 Advisory Opinion, Legal Consequences for States of the Continental Presence of South Africa in Namibia (South West Africa) notwithstanding Security Council Resolution 276 (1970), ICJ Reports, at 16; Akande supra note 4 , at 347.

79 SC Res. 276, 30 January 1970, § 2.

80 Nambia Advisory Opinion, supra note 78, §§ 114-116; Akande, supra note 4, at 347.

81 Akande, ibid., 347; see also Boschiero, supra note 27, 646-647.

82 See Akande, ibid., at 342; contra Tladi, supra note 9, at 8, who does not, however, consider the implications of the Namibia Advisory Opinion, supra note 78.

83 Also confirmed by Al Bashir (South Africa) decision, supra note 5, §§ 6-7; Al Bashir (DRC) decision, supra note 26, § 31. Those UN member States which are not party to the ICC would, on the one hand, be able to rely on the immunities of Al Bashir as having been waived by SC Res. 1593, 31 March 31 2005. However, they would not be obliged to cooperate in relation to his arrest or surrender, as they are not party to the 
rely on the customary international law immunity, nor the immunity provided for in the host state agreement or any other AU agreement. ${ }^{84}$ The conclusion of the North-Gauteng High Court that no customary law immunity applied in this instance was therefore correct in principle. However, its reasoning focussed exclusively on Article 27(2) of the Rome Statute, without explaining sufficiently its complex relationship with Article 98(1) and UNSC resolution 1593 (2005). ${ }^{85}$

\section{Status of the Relevant International Obligations in South African Domestic Law}

When confronted with the urgent application for the arrest and surrender of Al Bashir, the North-Gauteng High Court also had to consider whether South African domestic law contained a norm conflict, in relation to the obligation to arrest and surrender Al Bashir on the one hand, and to respect his immunity on the other. If such a conflict were to exist, the question arises as to which of these obligations under domestic law should prevail. In answering these questions one has to take into account the status of the relevant international obligations in South African domestic law. These include the relevant obligations in the ICC Statute, the status of the customary immunity of a head of state, that of the immunities contained in the host state agreement, the AU decision not to surrender any sitting head of state, the impact of UNSC Resolution 1593 (2005) on these obligations, as well as that of ICC Pre-Trial Chamber II's decision against South Africa. ${ }^{86}$

\section{A. Relevant Constitutional and Administrative Law Principles}

The starting point for the assessment of the status of international obligations in the domestic legal order is the Constitution, notably sections sections 231, 232 and 233. Section 231(4) confirms the dualist character of the national legal order in terms of treaties. It determines that: 'Any international agreement becomes law in the Republic when it is enacted into law by national legislation; but a self-executing provision of an agreement that has been approved by Parliament is law in the Republic unless it is inconsistent with the Constitution or an Act of Parliament.' It is important to note that the last part of section 231(4) that refers to selfexecuting treaty provisions has remained a dead-letter. On the few occasions which courts were confronted with the potential self-executing nature of a particular treaty provision, they

ICCSt. and therefore not bound to give effect to its section on state cooperation. See Akande, supra note 4, 347-348.

84 North-Gauteng High Court decision, supra note 2, § 31.

85 For criticism of the court's reliance on Art. 27(2) of the ICCSt. see Tladi, supra note 9, at 21.

86 North-Gauteng High Court decision, supra note 2 , § 1. 
either skirted the question or rejected it out of hand. ${ }^{87}$ Although this attitude may be unsatisfactory and is open to criticism, ${ }^{88}$ it confirms that South African courts are highly unlikely to apply directly a provision of any unimplemented treaty in the domestic legal order. $^{89}$

The status of customary international law is determined by section 232, in accordance with which 'Customary international law is law in the Republic unless it is inconsistent with the Constitution or an Act of Parliament'. Section 233 requires an international law friendly interpretation of legislation: 'When interpreting any legislation, every court must prefer any reasonable interpretation of the legislation that is consistent with international law over any alternative interpretation that is inconsistent with international law. ${ }^{90}$ Over the years the technique of international law friendly interpretation has become very important in ensuring that South African law remains in line with its international obligations, especially in situations where binding obligations have not yet been incorporated in the domestic legal order. $^{91}$ The Constitutional Court for its part has also reflected a clear determination to ensure that the Constitution and South African law are interpreted to comply with international law. ${ }^{92}$

Incorporation of treaties can take various forms, two of which are of relevance for the current analysis. The first concerns the adoption of an act of parliament that embodies the provisions of the respective treaty. The other form of treaty incorporation is through delegation by an act of parliament. Such legislation may grant the executive the power to bring a treaty into effect in municipal law by means of proclamation or notice in the Government Gazette. ${ }^{93}$ This proclamation effectively amounts to a simplified incorporation procedure, often for a large number of similar agreements. Very important in the present

87 See President of the RSA v Nello Quagliani; President of the RSA v Stephen Mark van Rooyen; and Steven William Goodwin v D-G, Department of Justice and Constitutional Development 2009 (4) 345 (CC), § 36; Claassen v Minister of Justice and Constitutional Development 2010 (6) SA 399 (WCC), § 36. See also E. de Wet, 'The Reception of International Law in the South African Legal Order: An Introduction' , in E. de Wet, H. Hestermeyer \& R. Wolfrum (eds), The Implementation of International Law in Germany and South Africa (Pretoria University Law Press, 2015) 23-50, for a discussion of the misunderstandings pertaining self-executing treaty provisions in South African law.

88 De Wet, ibid., at 35.

89 For the dualist character of the South African legal order, see also Hugh Glenister $v$ the President of the RSA, 2011 (3) SA 347 (CC), § 9.

90 International law friendly interpretation also gains particular significance when interpreting the constitutional Bill of Rights. In terms of sec. 39(1)(b), any court, tribunal must consider international law when interpreting the Bill of Rights. The text of the Constitution is available online at http://www.gov.za/documents/constitution-republic-south-africa-1996 (visited 30 July 2015).

91 For challenges facing South Africa in implementing treaties in various sub-areas of international law, see the South African chapters in De Wet, Hestermeyer \& Wolfrum, supra note 87.

92 Glenister decision, supra note 89, § 97.

93 De Wet, supra note 87 , at 31-32. 
context is that the Constitutional Court confirmed that (the rights and obligations contained in) a treaty enacted into law will have the same status in domestic law as the act through which it was incorporated. ${ }^{94}$

This implies that enacted treaties do not merely rank below the Constitution, the supreme law of South Africa, but can also rank below a parliamentary act - depending on the manner of its incorporation. ${ }^{95}$ While a treaty enacted into law by an act of parliament will enjoy the same status as other parliamentary acts, a treaty enacted into law through subordinate legislation (for example, a ministerial proclamation in the Government Gazette), will be on par with other subordinate legislation. ${ }^{96}$ This in turn confirms that it is the specific act of incorporation that determines the status of the rights and obligations stemming from the international agreement and not the parliamentary legislation that delegates the power of incorporation to the minister in question. ${ }^{97}$

The subordinate status of legislative activity of the executive is an important component of the separation of powers between the legislature and the executive and of the checks and balances necessary to prevent the executive branch from usurping the power of the legislature. ${ }^{98}$ Nevertheless, the social and political realities of the modern state make it inevitable that the legislature delegates the power to adopt legislation on specific issues to the executive. ${ }^{99}$ Due to the complexities of modern governance, legislatures are not in a position to foresee all the situations that need to be regulated in a particular area. Therefore, primary legislation often is articulated in general terms, while empowering high ranking members of the executive to enact secondary, detailed regulation. ${ }^{100}$ At the same time however, parliamentary (and judicial) control is crucial to ensure that legislative decisions by the executive remain within the limits of the delegated powers, in order to prevent a usurpation of powers by the executive. ${ }^{101}$

94 Glenister decision, supra note 89, § 102 stated clearly that the where treaty rights and obligations are incorporated into domestic law, such incorporation 'only transforms them into statutory rights and obligations that are enforceable in our law under the national legislation incorporating the agreement [emphasis added]'. See also J. Dugard, 'South Africa', in D. Sloss (ed), The Role of Domestic Courts in Treaty Enforcement (Cambridge University Press, 2009). 448-475, at 463; De Wet, supra note 87, at 33.

95 Dugard, ibid., 463; De Wet, supra note 87, at 33.

96 Dugard, ibid., 463; De Wet, ibid., at 33.

97 As suggested by Tladi, supra note 9, at 22.

98 See generally C. Hoexter, Administrative Law in South Africa (Juta, 2012), at 24.

99 Minister of Health $v$ New Clicks South Africa (Pty )Ltd, 2006 (2) SA 311 (CC), § 113; Hoexter, supra note 98, at 25.

100 Executive Council, Western Cape Legislature v President of the Republic of South Africa 1995 (4) SA 877, $\S 51$; Hoexter, supra note 98, at 25-26.

101 Western Cape decision, ibid., §§ 51, at 54; Hoexter, supra note 98, at 72-74. 
For this reason, delegated legislative power constitutes revocable, subsidiary authority, which in case of conflict with primary (parliamentary) legislation has to yield to the latter. The subordinate status of delegated legislation is confirmed by section 172 of the Constitution. This section allows the courts to set aside unconstitutional subordinate legislation without requiring subsequent confirmation of the unconstitutionality by the Constitutional Court. However, whenever a court sets aside parliamentary legislation on the ground of unconstitutionality, such a decision must subsequently be confirmed by the Constitutional Court. ${ }^{102}$ In the absence of mechanisms ensuring the subordinate and revocable nature of delegated legislative powers, the executive could grant itself the power to amend parliamentary legislation. This in turn would effectively abolish the oversight responsibility of parliament and do away with any distinction between primary and secondary (subordinate) legislation. $^{103}$

\section{B. Implications for the Relationship between Domesticated Obligations to Arrest and Surrender versus Immunities of Heads of State}

If one now turns to the Al Bashir case, it is important to keep in mind that the ICC Statute has been implemented by parliamentary legislation, as already set forth above. Of particular importance is section 10(9) which unambiguously states that a request for arrest and surrender by the ICC cannot be refused on the ground of the fact that the affected person is a head of state. ${ }^{104}$ Parliamentary legislation in the form of the DIPA also incorporated head of state immunity from civil and criminal jurisdiction to the extent afforded to them under customary international law. ${ }^{105}$ The immunities in the OAU Convention to which the hoststate agreement refers were however never domesticated through parliamentary legislation. ${ }^{106}$ Instead they were implemented for the duration of the summit, along with the host-state agreement, through subordinate legislation. The ministerial notice implementing these measures explicitly relied on section 5(3) of the DIPA, which permits the Minister of International Relations and Cooperation to engage in ad hoc immunity agreements and

102 See secs 172(1) and (2) of the Constitution, supra note 90; see also Hoexter, ibid., 263.

103 For a discussion of the general principles underlying the limitations of delegation of legislative powers, see Western Cape decision, supra note 100, §§ 62-63; ibid, separate opinion Mahomed, § 139; Hoexter, supra note 98 , at 262-263.

104 Du Plessis, supra note 1, 473-474. It is also conceded by Tladi, supra note 9, at 13-14, 21, despite his doubts as to whether sec. 8 of the Implementation Statute removes immunities for the purpose of prosecution by heads of state before national courts.

105 Sec. 4 of the DIPA, supra note 18.

106 See also the North-Gauteng High Court decision, supra note, §§ 28.2 and 28.4, which stated that the legislature made a clear choice not to make the OAU Convention directly enforceable in the Republic especially if one considers that the DIPA was adopted after ratification of the OAU Convention. 
implement them by means of ministerial notice. ${ }^{107}$ The AU decision not to surrender any sitting head of state to the ICC has never been implemented either by parliamentary or subordinate legislation.

UNSC Resolutions for their part are also not directly applicable in the domestic legal order, but dependant on domestication. There is not yet any act of parliament in place dedicated to the implementation of UNSC resolutions as such, although certain existing legislation can be used to give effect to UNSC resolutions on an ad hoc basis. ${ }^{108}$ UNSC Resolution 1593 (2005) has not been domesticated, but will have significant persuasive power in line with section 233 of the Constitution (and its own Chapter VII character). As far as the status of internationally binding judicial decisions such as that of ICC Pre-Trial Chamber II in the domestic law is concerned, a clear doctrine still has to emerge. ${ }^{109}$ In the one previous instance where the courts were confronted with the implementation of a binding international judicial decision in South Africa, they relied on the common law to give effect to the decision as there is not yet any adequate statutory framework in place. ${ }^{110}$ Similarly, as in the case of UNSC Resolution 1593 (2005), the courts will have to interpret existing legislation in line with such a binding judicial decision as far as reasonably possible.

When considering any potential conflict between section 10(9) of the Implementation Act and head of state immunity provided for in section 4 of the DIPA, one has to keep in mind that the latter only guarantees such immunity in so far as it is indeed provided for under customary international law. Since the UNSC has lifted the immunity of Al Bashir in UNSC Resolution 1593 (2005), section 4 of the DIPA has to be interpreted in a manner that gives

107 The notice, issued on 5 June in in Gazette No. 38860, supra note 17, determines that: 'In accordance with the powers vested in me by sec 5 (3) of the diplomatic Immunities and Privileges Act, 2001 (Act No. 37 of 2001), I hereby recognize the 'Agreement between the Republic of South Africa and the Commission of the African Union on the Material and Technical Organization of the Meetings of the 30th Ordinary Session of the Permanent Representatives Committee from 7 to 9 June 2015; the 27th Ordinary Session of the Executive Council from 10 to 12 June 2015 and the 25th Ordinary Session of the Assembly on 14 to 15 June 2015 in Pretoria (7 and 8 June 2015) and Johannesburg (10 to 15 June 2015), Republic of South Africa' for the purposes of granting the immunities and privileges as provided for in the Agreement between the Government of the Republic of South Africa and the Commission of the African Union as set out in the Notice.' See also North-Gauteng High Court decision, ibid., §§ 28.5, 29.

108 See D. Tladi, 'The United Nations Charter and the South African Legal Order', in De Wet, Hestermeyer \& Wolfrum, supra note 87, 88-110.

109 The binding character of these decisions is reflected by Art. 87(7) ICCSt.: 'Where a State Party fails to comply with a request to cooperate by the Court contrary to the provisions of this Statute, thereby preventing the Court from exercising its functions and powers under this Statute, the Court may make a finding to that effect and refer the matter to the Assembly of States Parties or, where the Security Council referred the matter to the Court, to the Security Council.'

110 See Government of the Republic of Zimbabwe v Fick (657/11) [2012] ZASCA 122; Government of the Republic of Zimbabwe v Louis Karel Fick 2013 (5) SA 325 (CC);For a discussion see E. de Wet, 'The Status and Effect of International Judicial Decisions in the South African Legal Order', in De Wet, Hestermeyer and Wolfrum, supra note 87, at 519-528. 
effect to this reality. In light of section 233 of the Constitution, section 4 of the DIPA has to be interpreted in accordance with UNSC Resolution 1593 (2005) and the Pre-Trial Chamber II decision against South Africa. Therefore it will not guarantee any customary immunities in this instance and there is no conflict with section 10(9) of the Implementation Act. The conclusion of the North-Gauteng High Court that no customary law immunities applied in this instance was therefore correct (even though the reasoning did not reflect the complexity of the issues at hand). ${ }^{111}$

The North-Gauteng High Court further correctly noted that unincorporated AU decisions such as the refusal to surrender sitting heads of state would at most have persuasive power in the Republic. ${ }^{112}$ However, whatever persuasive character such a decision might have is clearly diminished in this instance, in light of UNSC Resolution 1593 (2005). At the international level South Africa is obliged to give precedence to the implications of this resolution in accordance with Article 103 of the UN Charter. Domestic courts will take this into account when interpreting domestic law in accordance with international obligations.

As far as the immunities of the OAU Convention referred to in the host state agreement are concerned, the North-Gauteng High Court was also correct in concluding that their status in domestic legislation was that of secondary legislation. ${ }^{113}$ Therefore, any conflict between these immunities and Article 10(9) of the Implementation Act necessarily means that the latter would prevail and that South Africa would not be relieved of its obligation to arrest and surrender Al Bashir when attending the AU summit. ${ }^{114}$ There was some disagreement between the government and the North-Gauteng High Court as to whether the delegates covered by the immunity foreseen in the host-state agreement included all attendees, i.e. also state delegates, as opposed to only functionaries of the AU and inter-governmental organizations. ${ }^{115}$ However, even if one were to agree that the immunity covered all attendees of the summit, it does not change the fact that the immunity merely possesses the status of subordinate legislation in the Republic. Anything else would violate the separation of powers by allowing the executive to set aside parliamentary legislation. ${ }^{116}$

111 For criticism of the Court's reliance on Art. 27(2) of the ICCSt., see Tladi, supra note 9, at 21.

112 North-Gauteng High Court decision, supra note 2, § 28.13.3.

113 Ibid., § 31.

114 Ibid., § 28.12.

115 Ibid., §§ 28.6-28.7, 28.10.1, 28.1.3, 30. The North-Gauteng High Court concluded that the wording and structure of the host state agreement and the OAU Convention to which it refers, covers only AU functionaries. Tladi, supra note 9, at 20 on the other argued that the immunities cover all attendees of the summit.

116 This would indeed be the result if one were to agree with Tladi, ibid., 22 that it is not the ministerial notice that confers immunity, but the DIPA itself. In his argument Tladi refers to delegation in terms of sec. 6 of 
In fact, closer scrutiny suggests that the purpose of the host-state agreement may indeed have been to circumvent the obligations under the Implementation Act. Such a conclusion is not unreasonable if one considers the behaviour of the executive leading up and subsequent to Al Bashir's arrival for the AU summit. The mere fact that the government decided to host the AU summit is already indicative of its increased reluctance to give effect to its domestic obligations under the ICC Statute. After all, in 2009 South Africa urged Al Bashir not to attend the inauguration of President Zuma, as he would risk arrest and surrender to the ICC on his arrival in the country. The fact that South Africa decided to host the summit, without issuing a similar warning indicates a change in attitude towards the country's obligations under the ICC Statute.

Added to this is the reluctance on the part of the executive to take up consultations swiftly with the ICC in accordance with Article 97 of the ICC Statute, in situations where a member state expects difficulties in cooperation with the ICC in relation to arrest and surrender of a suspect. Already on 28 May 2015 the ICC Registry reminded the South African Ambassador to the Netherlands of its obligation to arrest and surrender Al Bashir in accordance with South Africa's obligations under the ICC Statute and to take up consultations with the ICC, if any difficulties in this regard were expected. ${ }^{117}$ However, South Africa only took up these consultations on 12 June 2015 - more than two weeks after this reminder by the Registry and only when Al Bashir was already on his way to South Africa. ${ }^{118}$ Meanwhile, it had entered the host-state agreement with the AU on 4 June 2015 and implemented it through subordinate legislation on 5 June 2015. One is therefore tempted to conclude that the government deliberately attempted to create a norm conflict which could be used as pretext during consultations with the ICC for not giving effect to its obligations under the ICC Statute.

Furthermore, during its consultations with South Africa on 12 June 2015, the Pre-Trial Chamber reminded the country that arguments very similar to those presented by South Africa were rejected by the ICC when forwarded by the DRC the year before. As far as the ICC was concerned, there was no doubt that South Africa had to arrest and surrender $\mathrm{Al}$ Bashir and as there was no further issue that was unclear, there could not be any further

the DIPA, supra note 18. The Minister however relied on section of this act. Be that as it may, regardless of whether one relies on the delegated powers in sec. 5 or sec. 6 , the result remains the same. It is further not clear why he relies on the Quagliani case, supra note 78, $\S 37$ as authority of his argument. It does not address the differences in status between international obligations introduced via primary and secondary legislation, respectively.

117 Al Bashir (South Africa) decision, supra note 5, § 3.

118 Ibid., § 4. 
consultations under Article 97 of the ICC Statute. ${ }^{119}$ A copy of the ICC Pre-Trial Chamber II decision to this effect was also provided to the South African Embassy in the Netherlands the same day. Yet, on 15 June 2015 the Embassy claimed that the consultation in accordance with Article 97 never took place. ${ }^{120}$ This was then followed by the flaunting of the domestic court order to arrest and surrender $\mathrm{Al}$ Bashir. ${ }^{121}$ While the court hearings pertaining to $\mathrm{Al}$ Bashir's arrest were ongoing in the North-Gauteng High Court, senior lawyers representing the government had requested an adjournment for the purposes of preparing a brief 24 page answering affidavit. While this adjournment was granted until 9h00 of the next day (15 June 2015), it was filed three hours later, without any explanation. ${ }^{122}$ It subsequently transpired that Al Bashir had left the country via the military airport in Pretoria during this time, despite assurances by the government lawyers that he was still in the country. ${ }^{123}$

\section{Concluding Remarks}

In the final analysis one is left with a sense that the behaviour of the South African government in the Al Bashir case was not rooted in a genuine concern for any ambiguities in the international and/ or domestic law. Had that been the case, it would never have organized the AU summit to begin with, or would at least have taken up consultations with the ICC at a point in time when it was still possible to either prevent Al Bashir from coming to South Africa, or give effect to the ICC Pre-Trial Chamber II order for arrest and surrender. Instead, the executive only entered consultations after having devised an immunity agreement that was intended to circumvent parliamentary legislation and, in the process, the country's obligations under the ICC Statute. When those consultations did not yield the result that the government desired, it rejected them and condoned Al Bashir's escape from the country.

Growing resentment amongst African states towards the ICC Prosecutor's strategy of what they perceive as unfair targeting of African leaders has been well-documented and will not be examined here. ${ }^{124}$ Whatever the merits of these criticisms may be, the government can only terminate South Africa's international and domestic obligations pertaining to the ICC

119 Ibid., § 8.

120 Registry Report on the consultations undertaken under Article 97 of the Rome Statute by the Republic of South Africa and the departure of Omar Al Bashir from South Africa on 15 June 2015 (ICC-02/05-01/09), 17 June 2015, §§ 5 and 11.

121 North-Gauteng High Court decision, supra note 2, § $36 \mathrm{ff}$.

122 Ibid., §§ 6-7.

123 Ibid., § 8.

124 See inter alia H. van der Wilt, 'Universal Jurisdiction under Attack. An Assessment of African Misgivings towards International Criminal Justice as Administered by Western States', 9 JICJ (2011) 1043, at 1043 ff; L. Oette, 'Peace and Justice, or Neither? The Repercussions of the Al-Bashir Case for International Criminal Justice in Africa and Beyond', 8 JICJ (2010) 345, at 345 ff. 
Statute by both withdrawing from the ICC Statute as provided for in its Article 127 and requesting parliament itself to suspend the Implementation Act. At this point in time South Africa is still a party to the ICC Statute and the Implementation Act is still in force in the Republic. As long as this is the case, the government is bound to cooperate with the ICC in relation to the arrest and surrender of Al Bashir when entering the country.

In the view of this author, the North-Gauteng High Court correctly determined that $\mathrm{Al}$ Bashir's immunity under customary law and the host-state agreement was lifted and that South Africa had to arrest and surrender him to the ICC. However, the reasoning of the court was at times confusing and vague. It should have elaborated more clearly on the tension between Articles 27(2) and 98 ICC Statute, as well as the manner in which UNSC Resolution 1593 (2005) resolved this tension. This in turned required a more thorough analysis of the wording of this resolution and its implications for Sudan as well as other states (notably those party to the ICC Statute). Whether the highest courts of the country will confirm the decision of the North-Gauteng High Court with better reasoning remains to be seen. On 16 September 2015 the North-Gauteng High Court denied leave to appeal to the Supreme Court of Appeal (the highest court in all non-constitutional matters), as sought by the government a month earlier. According to the North-Gauteng High Court, there was no live controversy between the parties anymore as President Bashir had left the country. An appeal would therefore have no practical effect. ${ }^{125}$ In addition, the North-Gauteng High Court held that the appeal did not have reasonable prospects of success, as it was unlikely that another court would come to a different conclusion. ${ }^{126}$ The government can however still seek leave to appeal directly with the Supreme Court of Appeal and are likely to attempt this in the near future. The matter will therefore occupy the South African judiciary and society for some time to come.

125 The Minister of Justice and Constitutional Development and Others $v$ the Southern African Litigation Centre, High Court of South Africa, Gauteng Division, Pretoria, Case Number: 27740/2015, 16 September $2015 \S 8$, available online at http://www.southernafricalitigationcentre.org/cases/ongoing-cases/southafricasudan-seeking-implementation-of-icc-arrest-warrant-for-president-bashir/ (visited 16 September 2015).

126 Ibid. 